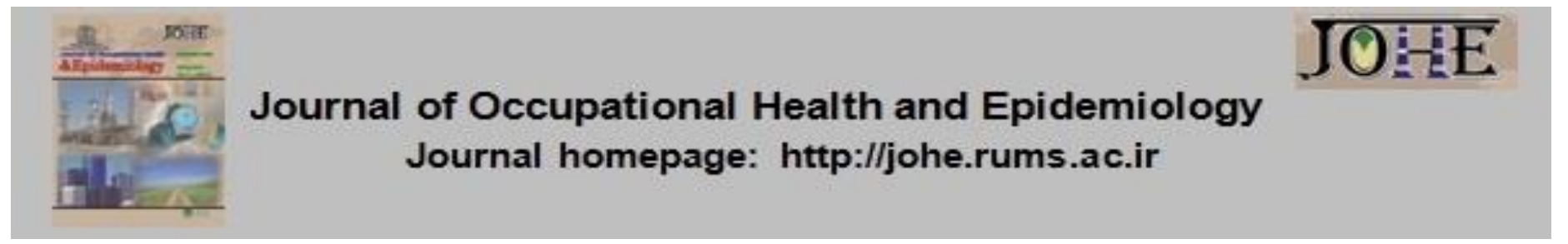

\title{
Association between Lead Exposure and Haematological Parameters among Roadside and Organized Panel Beaters in Enugu Metropolis, Nigeria
}

\author{
Kassy Wilson Chukwukasi ${ }^{* *}$, Aniwada Elias Chikee $^{2}$, Ossai Edmund Ndudi ${ }^{3}$, Aguwa Emmanuel \\ Nwabueze ${ }^{4}$ \\ 1. MPH, FWACP in Public Health, Consultant Public Health Physician, Dept. of Community Medicine, University of Nigeria Teaching \\ Hospital, Enugu, Nigeria. \\ 2. MPH, MSc, FWACP, FMCPH in Public Health, Consultant and Senior lecturer, Dept. of Community Medicine, University of Nigeria \\ Teaching Hospital, Enugu, University of Nigeria, Nsukka, Nigeria. \\ 3. MPH, MSc, FWACP in Public Health, Consultant Public Health Physician, Dept. of Community Medicine, Alex Ekwueme Federal \\ University Teaching Hospital Abakaliki, Abakaliki, Nigeria. \\ 4. Professor of Public Health, Dept. of Community Medicine, University of Nigeria Teaching Hospital, Enugu, Nigeria; University of \\ Nigeria, Nsukka, Nigeria.
}

\section{Citation: Chukwukasi KW, Chikee AE, Ndudi OE, Nwabueze AE. Association between Lead Exposure and Haematological Parameters among Roadside and Organized Panel Beaters in Enugu Metropolis, Nigeria. JOHE 2021; 10(1):48-56.}

\section{Article Info}

* Corresponding author:

Kassy Wilson Chukwukasi, E-mail:

kassy2kny@yahoo.com

\section{Article history \\ Received: Feb 2021 \\ Accepted: Mar 2021}

10.29252/johe.10.1.48

Print ISSN: 2251-8096 Online ISSN: 2252-0902

Peer review under responsibility of Journal of Occupational Health and Epidemiology

\section{Abstract}

Background: Haematotoxicity occurs following acute and chronic low dose exposures to lead. This study aimed to assess the association between occupational lead exposure and haematological parameters among roadside and organized panel beaters in Enugu Metropolis, Nigeria, 2018-19.

Materials and Methods: This was a cross-sectional and analytical study of 428 roadside and organized panel beaters. A multistage sampling technique was used to select participants. Blood lead and haematological parameters were analyzed using Atomic Absorption Spectrometer at $238.3 \mathrm{~nm}$ wavelength and Mindray Auto Haematology Analyzer, respectively. Comparative analyses were performed using Chi-square, Man Whitney U-test, T-test, correlation, and statistical significance.

Results: All the haematological parameters on both sectors of panel beaters had mean values within the normal reference values. 7 (3.3\%) on both sectors had abnormal haemoglobin and $4(1.9 \%)$ and $3(1.4 \%)$, respectively, had abnormal WBC. There was weak linear correlation among roadside and organized panel beaters of blood lead: $\mathrm{Hb}$ $(r=-0.061, P=0.371)$ and $(r=0.026, P=0.709), R B C(r=-0.036, P=0.596)$ and $(r=-0.004$, $P=0.956)$, and TWBC $(r=-0.044, P=0.524)$ and $(r=0.092, P=0.180)$, respectively.

Conclusion: Haematological parameters on both sectors were found to be within the normal reference range. There was a non-significant weak linear correlation between blood lead and the parameters. Haematological investigations should be included as part of routine biomonitoring in occupational health practice as an indicator of lead exposure.

Keywords: Occupational Health, Lead, Nigeria.

\section{Introduction}

Lead $(\mathrm{Pb})$ is a ubiquitous natural-occurring heavy metal found in many occupational processes or activities in inorganic and organic forms [1, 2]. Human exposure occurs through activities, including fossil fuel burning, mining, and manufacturing [3]. Though the use of $\mathrm{Pb}$ is as old as humankind, its poisoning reached an epidemic dimension by the $19^{\text {th }}$ and $20^{\text {th }}$ centuries, influenced by industrialization and its uncontrolled use in pure or alloyed forms $[4,5]$. Lead poisoning was known to be toxic in high doses, and the burden of toxicity was greatly underestimated 
since mostly the poisoning was clinically overt [3]. However, from the $20^{\text {th }}$ century to the present, most developed countries have halted $\mathrm{Pb}$ poisoning by restricting it in industry and using unleaded gasoline, except chronic exposures at lower levels. The reverse is the case in developing countries, where there are non-existent biomonitoring programs $[6,7]$. Lead enters the body through inhalation of dust and fumes, ingestion, and absorption by the skin [8 -10]. $\mathrm{Pb}$ poisoning effects are of respective target organs, e.g., haematologic, neurobehavioral, cardiotoxic, nephrotoxic, reproductive, and gastrointestinal effects [1, 11]. They occur in severe clinical and subclinical/asymptomatic forms [4].

Panel beaters are part of automobile technicians whose occupational activities of vehicle body repairs, cutting, soldering, and spray painting expose them to lead poisoning [12]. This occupational group operates in different forms and organizations. Some are observed along the roadsides with no safety rules, while others work in a formal sector governed by safety rules. [13] This setup may result in different occupational $\mathrm{Pb}$ exposure levels and haematoxicity effects.

The haematological effects of $\mathrm{Pb}$ poisoning occur following acute or chronic lead exposure interfering in the enzymatic steps in haeme synthesis pathway with a consequent reduction in red blood cells $[1,7,14]$. The impairment of haeme biosynthesis is first by inhibition of deltaaminolaevulinic acid dehydratase (ALA-D) with an elevation of protoporphyrin in the erythrocytes. This is dose-related, noted initially at a blood lead concentration of $10-20 \mu \mathrm{g} \mid \mathrm{dl}$ and completed at levels of $70-90 \mu \mathrm{g} \mid \mathrm{dl}$. It is second by inhibition of ferrochelatase, causing increased excretion of coproporphyrin and aminolevulinic acid (ALA) in the urine. This begins to rise at a blood lead concentration of $25-30 \mu \mathrm{g} \mid \mathrm{dl}[1,15]$, confirmed by marked reductions in blood haemoglobin and haematocrit levels and other erythrocytes after $\mathrm{Pb}$ exposure [16]. Other haematologic effects are direct toxic action of lead on leucopoiesis in lymphoid organs with an increase in total leucocytes, basophils, eosinophils, and lymphocytes, as well as lead inhibition of platelets aggregation in the bone marrow with an increase in platelet and platelet distribution width [15, 17].

The commonest outcome of lead haematopoietic toxicity is anaemia. At acute high-level exposure, lead poisoning causes haemolytic anaemia, while at chronic low-level exposure, it causes frank anaemia [11]. According to the Agency for Toxic Substances and Disease Registry (ATSDR-1999), children and adults with lead levels of $\geq 70 \mu \mathrm{g} \mid \mathrm{dl}$ and $\geq 80 \mu \mathrm{g} \mid \mathrm{dl}$, respectively, are anaemic. Also,
Schwartz et al. (1990) noted that $20 \%$ of children with blood lead above $60 \mu \mathrm{g} \mid \mathrm{dl}$ were anaemic [18]. A study in Iran found that the prevalence of anaemia among children at blood lead level $<5 \mu \mathrm{g} \mid \mathrm{dl}$ was $40 \%$, while another study in Egypt found $63.3 \%$ of children with blood lead $\geq 10 \mu \mathrm{g} \mid \mathrm{dl}$ $[19,20]$.

Few studies have been performed in Nigeria and other low-income countries on occupational $\mathrm{Pb}$ induced haematoxicity, none of which has compared the haemtoxicity effects of $\mathrm{Pb}$ exposure between occupational groups with different organizational structures affecting exposure. Available studies have assessed the occupational $\mathrm{Pb}$ exposure at higher thresholds [5]. The present study helps occupational health physicians understand the relationship between lead exposure and haematological parameters (HP) at varying levels of exposure for early intervention. Further, it can add to existing local knowledge and data. It can also help ascertain differences, if any, among workers with different organizational structures and occupational health practices. Therefore, this study aims at assessing the relationship between haematological parameters and lead exposure among roadside and organized panel beaters in Enugu Metropolis, Nigeria.

\section{Materials and Methods}

The study area is the Enugu metropolis, the capital of Enugu State in the southeast geo-political zone of Nigeria. The metropolis is constituted by three Local Government Areas (LGA) in Enugu State, including Enugu North, Enugu South, and Enugu East, and inhabited mostly by the Igbo ethnic group [21]. The panel beaters in this part of the state do not have a centralized garage, i.e., mechanic village. The roadside (informal) panel beaters are observed mainly in the streets; some are on streets close to spare parts markets. The organized (formal) panel beaters are those under government rules governed by factory, labor law, and workman compensation acts. They have an organizational structure that promotes safety precautions.

This was a comparative cross-sectional study of roadside and organized panel beaters in the Enugu metropolis. In this research, panel beaters and trainees who were 18 years and above, spent over one year with an exposure time of 8 hours and above, not involved in another job, and interested in participating in the study were included, while those with chronic diseases were excluded.

The minimum sample size for the study was determined using the formula for comparing two 
independent proportions [22], as well as $14.3 \%$ representing the proportion of Nigerian adults with blood lead levels $>20$ ugldl [23]. Standard normal deviate $(Z \alpha)$ of $1.96 \%$ and $80 \%$ power $(Z \beta)$ were included. A minimum sample size of 214 per sector was obtained after correcting the non-response rate, giving a sample size of 428 .

A multistage sampling technique was used for both roadside and organized panel beaters in this study. For the roadside panel beaters, the first stage was the selection of Enugu North among the three local government areas by simple random sampling as a zone using the balloting method. The second was the selection of one division out of the 5 in Enugu North LGA by simple random sampling using the balloting method. The third was the selection of 10 branches out of the 13 in Enugu North LGA by simple random sampling using the balloting method. Lastly, stratification and proportionate allocation of panel beaters from all the workshops within the selected branches were performed, and a total of 228 panel beaters were selected.

For the organized panel beaters, the first phase was the selection of Enugu North among the three local government areas by simple random sampling as a zone using the balloting method. The second was the proportionate allocation of government and private-owned company workers. There were a total of 70 and 220 panel beaters in government and private workshops, respectively. Using a ratio of 1:3, 56 panel beaters from government-owned workshops were selected out of 70 by simple random sampling using the balloting method. From the private-owned workshops, 170 panel beaters were selected. A total of 226 panel beaters were selected from the organized panel beaters considering missed and incomplete responses.

Data and sample were collected using research assistants who were three resident doctors and three phlebotomists. They were trained for two days, two hours per day, on sample collection procedures. Blood for the lead was collected under an aseptic procedure and analyzed using the standard lead stock solution at Project Development Agency (PRODA) Enugu. Blood sample collection was done in an enclosed and well-screened place. The venipuncture system was used to perform venipuncture, and the desired blood of 2-3mls was emptied into Ethylenediaminetetraacetic acid (EDTA) vacutainer bottles for blood lead estimation and complete blood count. The EDTA bottles containing the required amount of blood were gently shaken to ensure the samples not to be clotted. The samples for lead estimation were transported immediately to the laboratories using the Gio-style cold box after each day, accompanied by 5 and $10 \mathrm{ml}$ syringes, bleach, and gloves for maintenance of universal precautions. The blood samples were diluted to $10 \mathrm{ml}$ using deionized water because of accompanying cations and anions. The diluted samples were aspirated by the Buck Scientific Model 210 VGP Atomic Absorption Spectrometer (AAS) via a capillary tube at a wavelength of 283.3nm for $\mathrm{Pb}$ analysis. The blood samples for complete count were taken to Community Medicine Department Laboratory UNTH Ituku Ozalla for analysis using Mindray Auto Haematology Analyzer. The results of analyses were entered into a proforma or spreadsheet for the blood lead levels and HP.

Data were analyzed using Statistical Package for Social Science (SPSS) version 25. Categorical variables were summarized using frequencies and proportions, while continuous variables were summarized using mean, standard deviation, median, and inter-quartile range for skewed data. The lead levels in blood were categorized using a cut-off of $10 \mu \mathrm{g} \mid \mathrm{dl}$ and above as $\mathrm{Pb}$ poisoning [24]. Prevalence of $\mathrm{Pb}$ poisoning was noted as a proportion of panel beaters with blood lead of $10 \mu \mathrm{g} \mid \mathrm{dl}$ and above. Haematological parameters were categorized into normal and abnormal using reference values. Comparison of variables was managed using Man Whitney U- (MHU) test, Chisquare test, and T-test. The relationship between blood lead (BPb) and HP was determined using correlation analyses. The level of significance was set at $\mathrm{P}<0.05$.

Ethical approval was obtained from the Health Research Ethics Committee of the University of Nigeria Teaching Hospital, Ituku Ozalla (No. NHREC/05/01/200BB-FWA00002458-

IRB00002323). Permission was obtained from unions of roadside and organized panel beaters in Enugu State. Informed consent was obtained from participants.

\section{Results}

The median $\mathrm{Pb}$ levels were $3.0 \mu \mathrm{g} \mid \mathrm{dl}$ and $16.0 \mu \mathrm{g} \mid \mathrm{dl}$ among roadside and organized panel beaters, respectively. About two-third and one-third of roadside and organized panel beaters, respectively, had $\mathrm{Pb}$ level $<10 \mu \mathrm{g} \mid \mathrm{dl}$, while 79 $(36.4 \%)$ and 138 (63.6\%) of roadside and organized panel, respectively, had abnormal levels of $\mathrm{Pb}$. The differences between the two sectors were found to be significant $(P<0.0001)$ (Table 1$)$. 
Table 1. Blood lead estimation among roadside and organized panel beaters

\begin{tabular}{|c|c|c|c|c|c|c|c|}
\hline \multirow{2}{*}{\multicolumn{2}{|c|}{ Variables }} & \multicolumn{2}{|c|}{$\begin{array}{l}\text { Roadside panel beaters } \\
\qquad N=214\end{array}$} & \multicolumn{2}{|c|}{$\begin{array}{l}\text { Organized panel beaters } \\
\qquad N=214\end{array}$} & \multicolumn{2}{|c|}{ Statistical analysis } \\
\hline & & Frequency & Percent & Frequency & Percent & Test & P-value \\
\hline \multirow[b]{2}{*}{ Blood lead } & Median & $3.0 \mu \mathrm{g} \mid \mathrm{dl}$ & - & $16.0 \mu \mathrm{g} \mid \mathrm{dl}$ & - & \multirow{2}{*}{$\begin{array}{l}\text { MHU } \\
-2.720\end{array}$} & \multirow[b]{2}{*}{$<0.0001^{*}$} \\
\hline & $\begin{array}{l}\text { Inter-quartile } \\
\text { range }\end{array}$ & $0-20 \mu \mathrm{g} \mid \mathrm{dl}$ & - & $\begin{array}{c}4- \\
31.3 \mu \mathrm{g} \mid \mathrm{dl}\end{array}$ & - & & \\
\hline \multirow{2}{*}{$\begin{array}{c}\text { Categories } \\
\text { of blood } \\
\text { lead }\end{array}$} & $\begin{array}{c}\text { Normal / } \\
\text { unexposed }\end{array}$ & 135 & 64.0 & 76 & 36 & \multirow{2}{*}{$\begin{array}{c}\text { Chi - square } \\
32.539\end{array}$} & \multirow{2}{*}{$<0.0001^{*}$} \\
\hline & $\begin{array}{l}\text { Abnormal / } \\
\text { poisonous }\end{array}$ & 79 & 36.4 & 138 & 63.6 & & \\
\hline
\end{tabular}

All the HP on both sectors of panel beaters had mean values within the normal reference values. The mean differences in MCHC, RDWc (\%), Neutro (\%), Lymph, Lymph (\%), Mono (\%), and PDWc (\%) between the two sectors were found to be significant. Very few respondents among roadside and organized sectors had abnormal HP, $7(3.3 \%)$ of respondents on both sectors had abnormal haemoglobin, $3(1.4 \%)$ of roadside and $12(5.6 \%)$ of organized sector respondents had abnormal RBCs, 4 (1.9\%) of roadside and 3 (1.4\%) of organized sector respondents had abnormal WBC, and $11(5.1 \%)$ of roadside and 7 (3.3\%) of organized sector respondents had abnormal platelets (Tables 2 and 3).

Table 2. Mean distribution of haematogical parameters among roadside and organized panel beaters

\begin{tabular}{|c|c|c|c|c|c|c|}
\hline \multirow[b]{2}{*}{ Parameters } & \multicolumn{2}{|c|}{$\begin{array}{l}\text { Roadside panel beaters } \\
\qquad(\mathrm{N}=214)\end{array}$} & \multicolumn{2}{|c|}{$\begin{array}{l}\text { Organized panel beaters } \\
\qquad(\mathrm{N}=214)\end{array}$} & \multicolumn{2}{|c|}{ Statistical analysis } \\
\hline & Mean & Std dev. & Mean & Std dev. & T-test & P-value \\
\hline $\mathrm{Hb}(\mathrm{g} \mid \mathrm{dl})$ & 13.65 & 1.33 & 13.65 & 1.48 & -0.014 & 0.989 \\
\hline Haem (\%) & 41.43 & 5.02 & 41.93 & 4.56 & -1.077 & 0.282 \\
\hline $\operatorname{RBC}\left(10^{12} \mid \mathrm{L}\right)$ & 5.24 & 2.37 & 5.24 & 0.81 & 0.017 & 0.987 \\
\hline MCV (fl) & 80.98 & 11.56 & 80.08 & 9.58 & 0.881 & 0.379 \\
\hline $\mathrm{MCH}(\mathrm{pg})$ & 27.41 & 2.86 & 26.60 & 5.46 & 1.909 & 0.057 \\
\hline $\mathrm{MCHC}(\mathrm{g} \mid \mathrm{dl})$ & 32.97 & 1.87 & 32.34 & 2.97 & 2.721 & $0.007^{*}$ \\
\hline RDWc (\%) & 14.93 & 0.70 & 15.56 & 2.49 & -3.523 & $<0.001^{*}$ \\
\hline RDWSD (fl) & 43.36 & 3.77 & 42.88 & 4.16 & 1.250 & 0.212 \\
\hline TWBC $\left(10^{9} \mid \mathrm{L}\right)$ & 5.74 & 1.91 & 6.01 & 1.93 & -1.443 & 0.150 \\
\hline Neut. (109|L) & 2.72 & 2.82 & 2.45 & 1.24 & 1.287 & 0.199 \\
\hline Neut. (\%) & 41.53 & 10.53 & 38.88 & 11.84 & 2.447 & $0.015^{*}$ \\
\hline Lymph $\left(10^{9} \mid \mathrm{L}\right)$ & 2.69 & 1.44 & 2.97 & 1.29 & -2.087 & $0.037^{*}$ \\
\hline Lymph (\%) & 46.27 & 11.03 & 49.89 & 13.79 & -3.005 & $0.003^{*}$ \\
\hline Monocytes $\left(10^{9} \mid \mathrm{L}\right)$ & 0.71 & 0.39 & 0.65 & 0.33 & 1.853 & 0.065 \\
\hline Mono (\%) & 11.88 & 4.81 & 10.85 & 3.87 & 2.448 & $0.015^{\star}$ \\
\hline Platelets $\left(10^{9} \mid \mathrm{L}\right)$ & 222.30 & 87.72 & 214.81 & 59.63 & 1.034 & 0.302 \\
\hline MPV (fl) & 8.94 & 0.97 & 9.12 & 1.09 & -1.839 & 0.067 \\
\hline PDWc (\%) & 15.67 & 0.51 & 20.98 & 10.06 & -7.719 & $<0.001^{*}$ \\
\hline PCT (\%) & 0.20 & 0.09 & 0.19 & 0.07 & 1.300 & 0.194 \\
\hline
\end{tabular}

There was a very weak linear relationship between $\mathrm{Pb}$ exposure and HP among panel beaters on both sectors, which were mostly negative except for few parameters. The relationship was found not to be significant except for the percentage of neutrophils and monocytes. The scatter plot showed crowding of the haemoglobin, RBC, WBC, and platelet values mostly around the normal values but at lower $\mathrm{BPb}$ for roadside panel beaters compared to those of the organized (Table 4, Figs. 1-8). 
Table 3. Distribution of haematological parameters among roadside and organized panel beaters

\begin{tabular}{lccccc}
\hline & & \multicolumn{2}{c}{ Roadside panel beaters $(\mathbf{N}=\mathbf{2 1 4})$} & \multicolumn{2}{c}{ Organized panel beaters (N = 214) } \\
\hline \multicolumn{1}{c}{ Parameters } & (Reference values) & Normal & Abnormal & Normal & Abnormal \\
\hline $\mathrm{Hb}(\mathrm{g} \mid \mathrm{dl})$ & $(10.69-18.76)$ & $207(96.7)$ & $7(3.3)$ & $207(96.7)$ & $7(3.3)$ \\
\hline $\mathrm{Haem}(\%)$ & $(31.8-61.83)$ & $208(97.2)$ & $6(2.8)$ & $210(98.1)$ & $4(1.9)$ \\
\hline $\mathrm{RBC}\left(10^{12} \mid \mathrm{L}\right)$ & $(3.61-6.97)$ & $211(98.6)$ & $3(1.4)$ & $202(94.4)$ & $12(5.6)$ \\
\hline $\mathrm{MCV}(\mathrm{fl})$ & $(69.71-103.23)$ & $200(93.5)$ & $14(6.5)$ & $185(86.4)$ & $29(13.6)$ \\
\hline $\mathrm{MCH}(\mathrm{pg})$ & $(23.30-34.16)$ & $189(88.3)$ & $25(11.7)$ & $171(79.9)$ & $43(20.1)$ \\
\hline $\mathrm{MCHC}(\mathrm{g} \mid \mathrm{dl})$ & $(29.74-37.16)$ & $209(97.7)$ & $5(2.3)$ & $208(97.2)$ & $6(2.8)$ \\
\hline RDWCV $(\%)$ & $(11.70-18.66)$ & $214(100)$ & $0(0.0)$ & $211(98.6)$ & $3(1.4)$ \\
\hline TWBC $\left(10^{9} \mid \mathrm{L}\right)$ & $(3.28-11.23)$ & $210(98.1)$ & $4(1.9)$ & $211(98.6)$ & $3(1.4)$ \\
\hline Neut. $\left(10^{9} \mid \mathrm{L}\right)$ & $(0.65-5.50)$ & $207(96.7)$ & $7(3.3)$ & $204(95.3)$ & $10(4.7)$ \\
\hline Neut. $(\%)$ & $(17.57-67.46)$ & $209(97.7)$ & $5(2.3)$ & $198(92.5)$ & $16(7.5)$ \\
\hline Lymph $\left(10^{9} \mid \mathrm{L}\right)$ & $(0.77-4.78)$ & $211(98.6)$ & $3(1.4)$ & $206(96.3)$ & $8(3.7)$ \\
\hline Lymph $(\%)$ & $(11.98-66.91)$ & $207(96.7)$ & $7(3.3)$ & $187(87.4)$ & $27(12.6)$ \\
\hline Mono $\left(10^{9} \mid \mathrm{L}\right)$ & $(0.21-1.02)$ & $183(85.5)$ & $31(14.5)$ & $184(86.0)$ & $30(14.0)$ \\
\hline Mono $(\%)$ & $(4.30-15.17)$ & $170(79.4)$ & $44(20.6)$ & $189(88.3)$ & $25(11.7)$ \\
\hline Platelets $\left(10^{9} \mid \mathrm{L}\right)$ & $(85.93-348.20)$ & $203(94.9)$ & $11(5.1)$ & $207(96.7)$ & $7(3.3)$ \\
\hline
\end{tabular}

Table 4. Relationship between estimated lead levels and haematological parameters

\begin{tabular}{ccccc}
\hline & \multicolumn{2}{c}{ Roadside panel beaters (N = 214) } & \multicolumn{2}{c}{ Organized panel beaters (N = 214) } \\
\hline Parameters & $\mathbf{R}$ & $\mathbf{P}$-value & $\mathbf{R}$ & P-value \\
\hline $\mathrm{Hb}(\mathrm{g} \mid \mathrm{dl})$ & -0.061 & 0.371 & 0.026 & 0.709 \\
\hline Haem $(\%)$ & -0.090 & 0.191 & 0.016 & 0.821 \\
\hline RBC $\left(10^{12} \mid \mathrm{L}\right)$ & -0.036 & 0.596 & -0.004 & 0.958 \\
\hline MCV $(\mathrm{fl})$ & -0.005 & 0.948 & 0.034 & 0.616 \\
\hline MCH $(\mathrm{pg})$ & -0.062 & 0.368 & -0.041 & 5.48 \\
\hline MCHC $(\mathrm{g} \mid \mathrm{dl})$ & 0.039 & 0.570 & -0.032 & 0.645 \\
\hline RDWCV $(\%)$ & -0.018 & 0.788 & -0.064 & 0.349 \\
\hline RDWSD $(\mathrm{fl})$ & -0.023 & 0.736 & 0.014 & 0.180 \\
\hline TWBC $\left(10^{9} \mid \mathrm{L}\right)$ & -0.044 & 0.524 & 0.092 & 0.162 \\
\hline Neut. $\left(10^{9} \mid \mathrm{L}\right)$ & -0.008 & 0.909 & 0.096 & 0.539 \\
\hline Neut. $(\%)$ & 0.169 & 0.014 & 0.042 & 0.778 \\
\hline Lymph $\left(10^{9} \mid \mathrm{L}\right)$ & -0.067 & 0.331 & 0.045 & 0.761 \\
\hline Lymph $(\%)$ & -0.066 & 0.339 & -0.019 & 0.181 \\
\hline Monocytes $\left(10^{9} \mid \mathrm{L}\right)$ & -0.058 & 0.402 & -0.021 & 0.319 \\
\hline Mono $(\%)$ & -0.160 & 0.019 & -0.092 & 0.116 \\
\hline Platelets $\left(10^{9} \mid \mathrm{L}\right)$ & 0.054 & 0.435 & -0.068 & 0.800 \\
\hline MPV $(\mathrm{fl})$ & -0.049 & -0.108 & 0.294
\end{tabular}

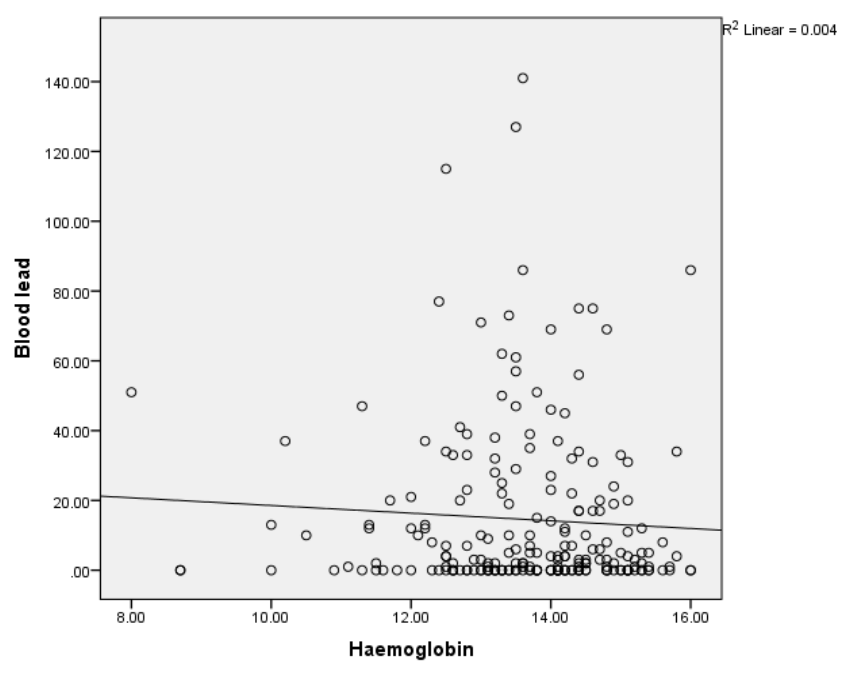

Fig.1. A scatter plot showing the correlation between blood lead levels and haemoglobin among roadside panel beaters

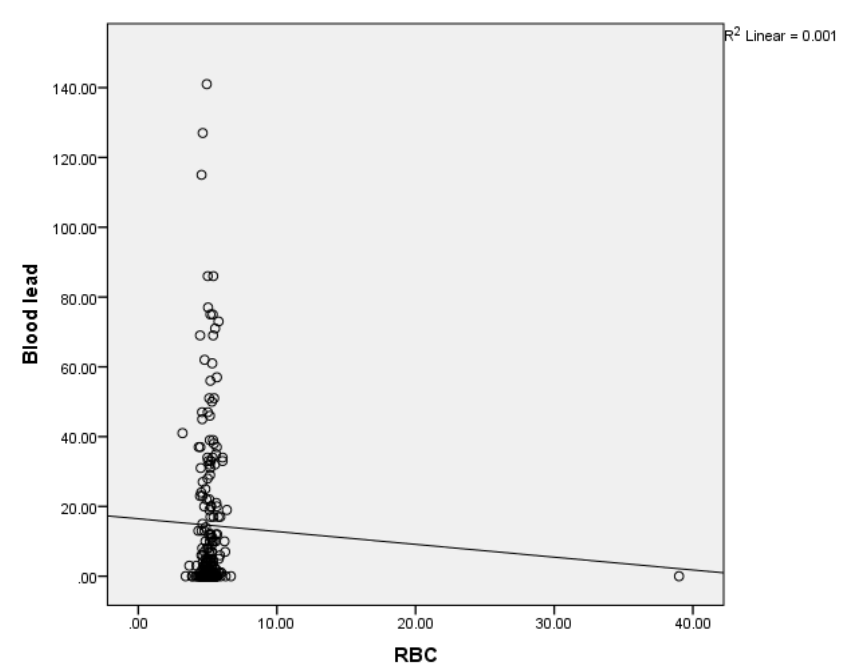

Fig. 2. A scatter plot showing the correlation between blood lead levels and red blood cells among roadside panel beaters 


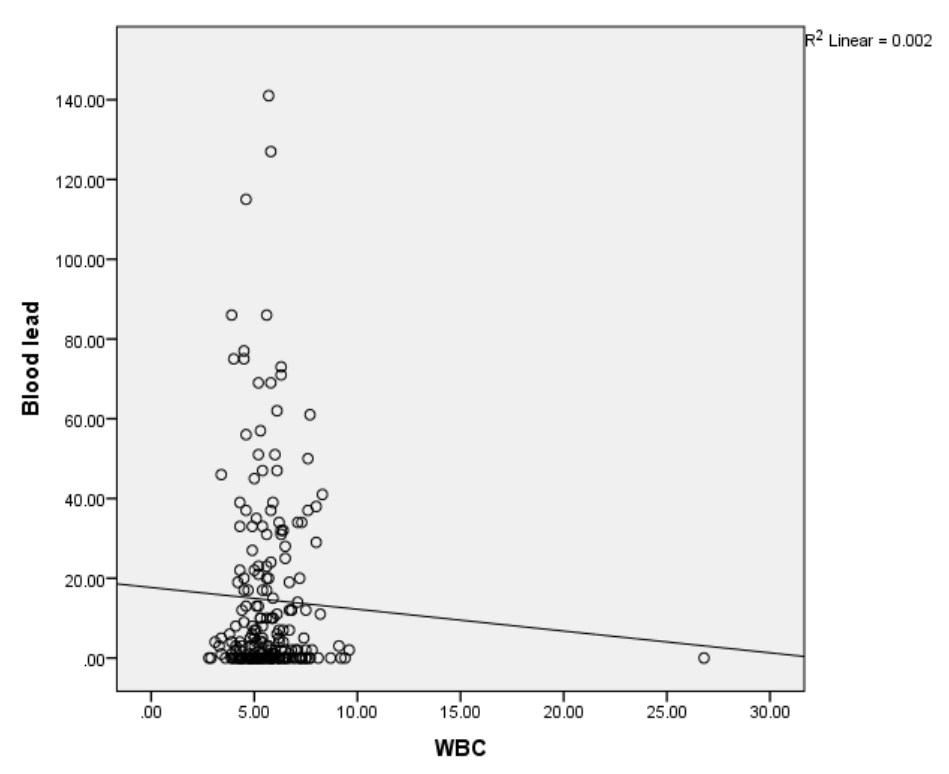

Fig. 3. A scatter plot showing the correlation between blood lead levels and White blood cells among roadside panel beaters

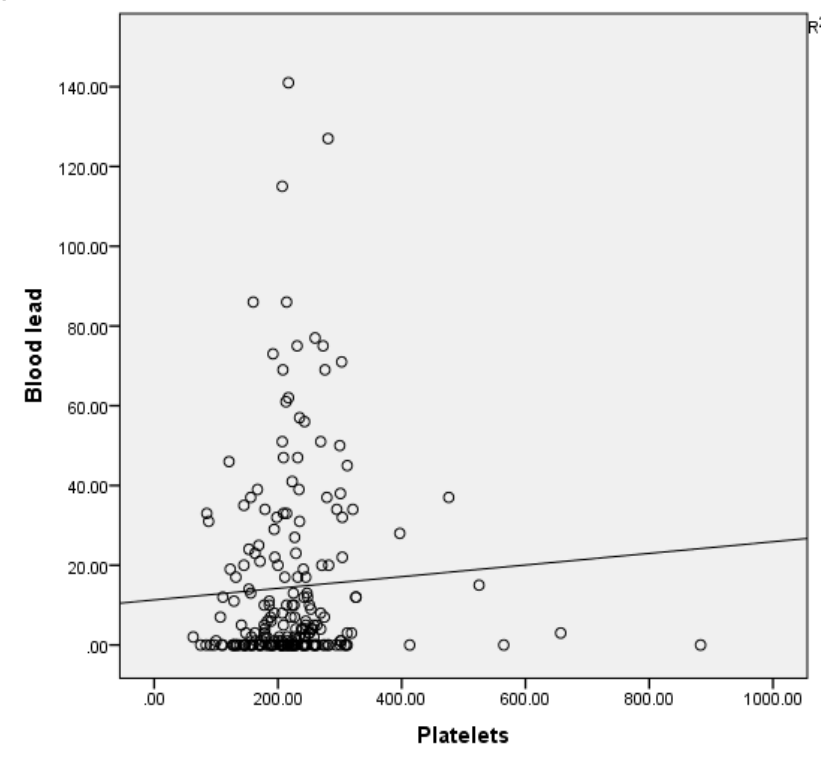

Fig. 4. A scatter plot showing the correlation between blood lead levels and platelets among roadside panel beaters

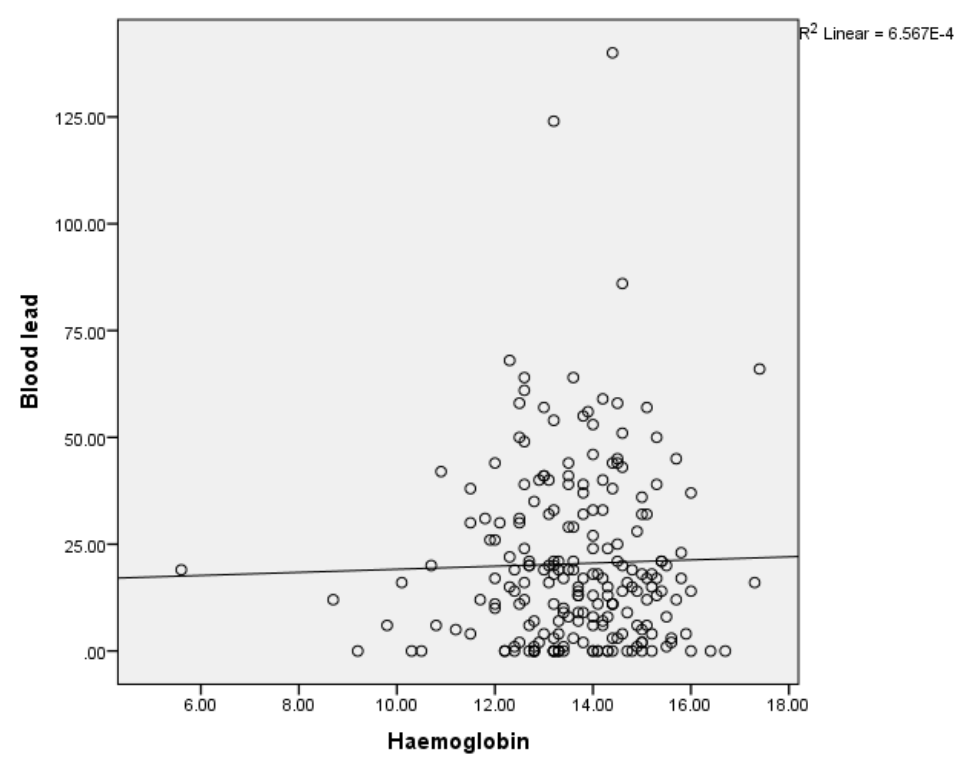

Fig. 5. A scatter plot showing the correlation between blood lead levels and haemoglobin among organized panel beaters

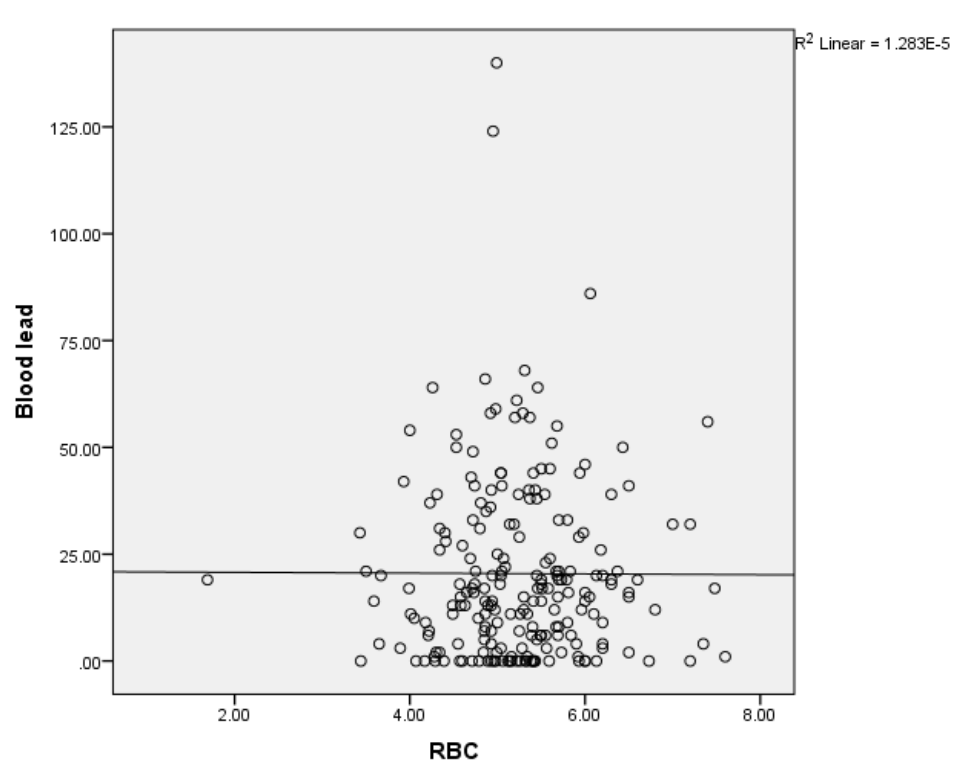

Fig. 6. A scatter plot showing the correlation between blood lead levels and red blood cells among organized panel beaters

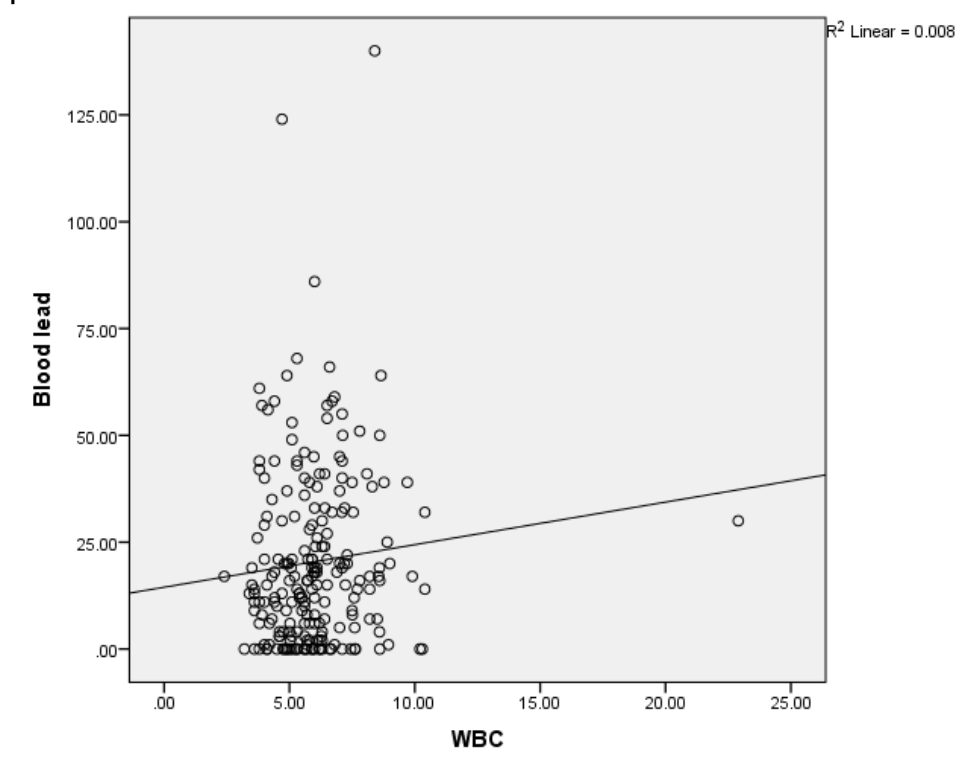

Fig. 7. A scatter plot showing the correlation between blood lead levels and white blood cells among organized panel beaters

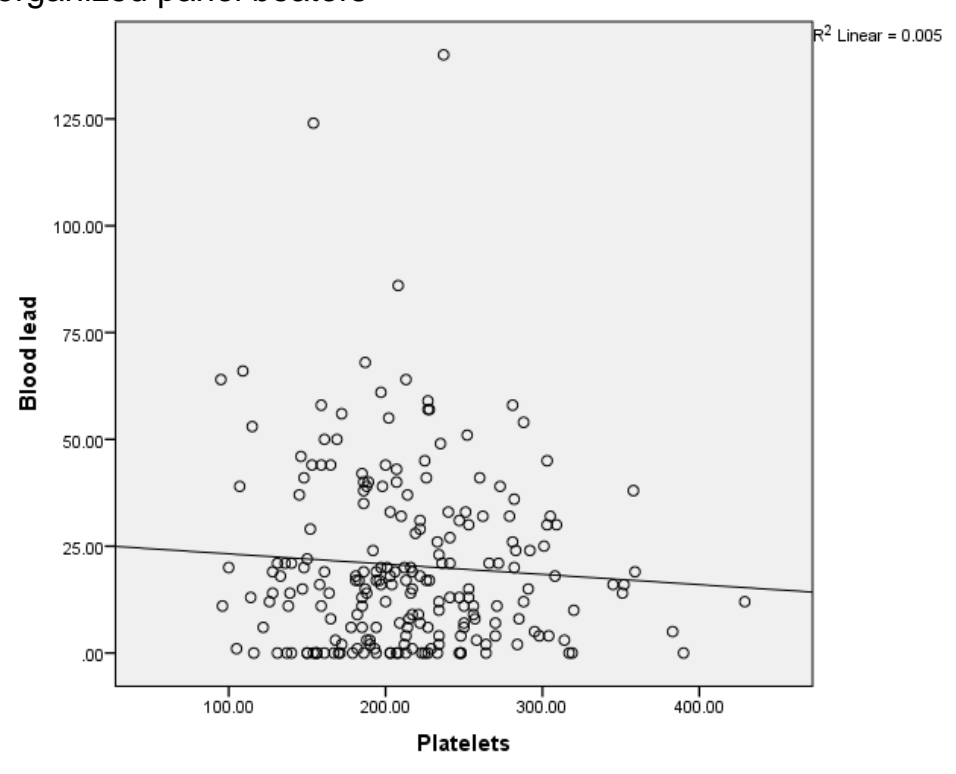

Fig. 8. A scatter plot showing the correlation between blood lead levels and platelets among organized panel beaters 
Table 5. Parameters and their meanings

\begin{tabular}{ll}
\hline Parameters & Definition or full meaning \\
\hline $\mathrm{Hb}$ & Haemoglobin \\
\hline $\mathrm{Haem}(\%)$ & Haematocrit \\
\hline $\mathrm{MCV}$ & Red Blood Cells \\
\hline $\mathrm{MCH}$ & Mean Corpuscular Volume: the average volume of a red blood corpuscle \\
\hline MCHC & $\begin{array}{l}\text { Mean Corpuscular Haemoglobin: the average mass of heamoglobin per red blood cell in a sample } \\
\text { given volume of a packed red blood cell; it is haemoglobin divided by haemotocrit. }\end{array}$ \\
\hline RDWCV (\%) & $\begin{array}{l}\text { Red Blood Cell Distribution Width: it is a measure of the variation range of red blood cell volume as } \\
\text { part of standard complete blood count. }\end{array}$ \\
\hline RDWSD & $\begin{array}{l}\text { Red Cell Distribution Width Standard Deviation: it is a measure of the range in the volume and size } \\
\text { of red blood cells. }\end{array}$ \\
\hline TWBC & Total White Blood Cells \\
\hline Neut & Neutrophils as a component of TWBC \\
\hline Neut (\%) & Neutrophil as a percentage of TWBC \\
\hline Lymph & Lymphocytes \\
\hline Lymph (\%) & Lymphocytes as a percentage of TWBC \\
\hline Mono & Monocytes \\
\hline Mono (\%) & Monocytes as a percentage of TWBC \\
\hline Platelets & Platelets help the blood to clot and stop bleeding. \\
\hline MPV & Mean Platelets Volume: the average size of platelets found in the blood \\
\hline PDWc (\%) & Platelet Distribution Width: it causes activation of coagulation. \\
\hline PCT (\%) & $\begin{array}{l}\text { Platelet Count Test or Plateletcrit: it is the volume occupied by platelets in the blood as a } \\
\text { percentage. }\end{array}$ \\
\hline
\end{tabular}

The HP and the respective meanings are described below (Table 5).

\section{Discussion}

The haematogical effects of $\mathrm{Pb}$ exposure are dose-dependent; notably, the parameters are inhibited at increasing exposure to $\mathrm{Pb}$ levels (14, 15). Occupational $\mathrm{Pb}$ exposure is considered normal/unexposed at less than $10 \mu \mathrm{g} \mid \mathrm{dl}$, above which it becomes poisonous; thus, workers must be moved away from the exposure source (24). The noted effects at the poisonous $\mathrm{Pb}$ levels are clinically overt and consequent irreversible health outcomes (24). Following the advent of preventive measures that have halted the burden of $\mathrm{Pb}$ toxicities, concerns have shifted to the effects of subclinical toxicities at chronic low doses (4).

Haemoglobin effect from occupational $\mathrm{Pb}$ exposure has been widely studied, while few studies exist on effects on other blood cells, mostly in Nigeria compared to other countries. This study assesses all $\mathrm{HP}$ and their relationship with $\mathrm{Pb}$ levels. The BPb levels in this work show a significant difference in the median $\mathrm{BPb}$ of the two sectors. The roadside panel beaters have median $\mathrm{BPb}$ within the normal level compared to the organized panel beaters whose median BPb levels are within the abnormal level. The erythrocytic effects of $\mathrm{Pb}$ exposure are known to be deranged at $\mathrm{Pb}$ levels of $10 \mu \mathrm{g} \mid \mathrm{dl}$ and above and become completed at very high levels (14). The effects on the white blood cells and the platelets are due to the direct toxic action of $\mathrm{Pb}$ on lymphoid organs and bone marrow with an increase in total leucocytes, basophils, eosinophils, and lymphocytes, as well as platelet and platelet distribution width $(15,16)$. In the present research, the mean blood cell values of all the haematological parameters determined on both sectors were found to be within normal references. These values were comparable with the study in Ghana, where haematological values of a healthy population were determined (25). This is because the majority of workers in both sectors have $\mathrm{BPb}$ levels within the normal range, and if in the poisoning, they are still within an acceptable range of early onset of hematological effects. The normal mean values of parameters were supported by the majority of workers, $>70 \%$ in both sectors with HP within the normal reference values. These findings confirmed studies in Nigeria, Jordan, Iraq, and Taiwan with similar $\mathrm{Pb}$ levels within an acceptable range $(5,13,26,27)$. However, they differed from studies among children done in Egypt and Iran, where a higher proportion of children were found to have higher mean and abnormal values of HP with $\mathrm{BPb}$ within normal values and acceptable range $(19,20,28)$. This is due to immature developing bone marrow compared to adults. Lead exposure cause higher direct toxicity in the bone marrow and increase haemolysis of erythrocytic cells. Public 
health is of concern because of "occupational takehome lead" from clothing, skin, as well as an environmental spillover of $\mathrm{Pb}$ particles in the soil, air, and water. Occupational control of personal and environmental hygiene practices is recommended.

The lead exposure on HP found in this study showed a non-significant linear relationship, very weakly correlated in both sectors of panel beaters. Despite linearity, this non-significant correlation is insufficient evidence to predict the relationship between the two variables. The two variables are very close and crowded to zero; however, the slight linearity is potential for toxic outcomes, which should be considered for removal till blood levels are brought to normal or acceptable levels. This is illustrated in the scatter plot in Figs. 1-8, where the $\mathrm{HP}$ is crowded within normal and acceptable values of $\mathrm{BPb}$ but at lower $\mathrm{BPb}$ among the roadside compared to the organized panel beaters. These results are due to the high frequency of normal and acceptable values of estimated $\mathrm{Pb}$ levels, chronic nature of exposure to lead, age group of workers, and possibly the nutritional status of workers. It is observed that most workers undertake three nutritious square meals obtainable near their workplace, which are cheaper and adequate. These findings are in line with those of studies in Nigeria, Iran, India, Taiwan, and Italy (5, $7,13,16,29)$. The findings further show that there could be some uncontrolled $\mathrm{Pb}$ exposure with poor haematological outcomes characterized by anaemia, as well as increased leucocytes and platelet aggregation with potential for coagulopathy. This is evident among children in a study in Egypt, where a significant and strong correlation has been found. Good occupational control practices, adequately put in place and adhered to, can help reduce take-home lead, environmental spillover $\mathrm{Pb}$, as well as keeping the haematological parameters within normal levels.

Haematological investigations should be included as part of routine biomonitoring in occupational health practice as an indicator of the health impact of $\mathrm{Pb}$ exposure in addition to personal and environmental hygiene practices. The study is specific to one area, and, therefore, the findings cannot be generalized. It is cross-sectional, and the findings are limited to the period of the study.

\section{Conclusion}

At normal and acceptable $\mathrm{Pb}$ exposures, $\mathrm{HP}$ is found to be within normal limits. The few abnormalities are due to few high values of $\mathrm{Pb}$ levels. The relationship is found to be nonsignificant and weakly correlated.

\section{Acknowledgement}

The researchers want to express sincere gratitude to subjects who were available for invasive blood collection for this research. We also appreciate the assistance of the Enugu North panel beaters unions in reaching to their workers.

\section{Conflict of interest: None declared.}

\section{References}

1. Okediran BS, Biobaku KT, Olaifa FH, Atata AJ. Haematological and antioxidant response to lead toxicity in male whisker rats. Ceylon Journal of Science 2017; 46(2):31-7.

2. Gidlow DA. Lead toxicity. Occup Med (Lond) 2004; 54(2):76-81.

3. Agency for Toxic Substances and Disease Registry, Division of Toxicology and Human Health Services. Lead - ToxFAQs TM. Washington, D.C., United States: Department of Health and Human Services, Agency for Toxic Substances and Disease Registry; 2007 Aug.

4. Riva MA, Lafranconi A, D'Orso MI, Cesana G. Lead poisoning: historical aspects of a paradigmatic "Occupational and environmental disease. Saf Health Work 2012; 3(1):11-6.

5. Ukaejiofo EO, Thomas N, lke SO. Haematological assessment of occupational exposure to lead handlers in Enugu urban, Enugu State, Nigeria. Niger J Clin Pract 2009; 12(1):58-64.

6. Kordas K, Ravenscroft J, Cao Y, McLean EV. Lead Exposure in Low and Middle-Income Countries: Perspectives and Lessons on Patterns, Injustices, Economics and Politices. Int J Environ Res Public Health 2018; 15(11):2351.

7. Fontana $V$, Baldi R, Franchini M, Gridelli P, Neri $R$, Palmieri $F$, et al. Adverse haematological outcome and environmental lead poisoning. $\mathrm{J}$ Expo Anal Environ Epidemiol 2004; 14(2): 18893.

8. Saliu A, Adebayo O, Kofoworola O, Babatunde $O$, Ismail A. Comparative assessment of blood lead levels of automobile technicians in organised and roadside garages in Lagos, Nigeria. J Environ Public Health 2015; 2015:976563.

9. Lawal MA, Uzairu A, Sallau MS. A study of the Bioavailability and Impact of Habits on the Occupational Exposure of Electronic Repairers to Lead $(\mathrm{Pb})$, Cadmium (Cd), and Chromium (Cr) in Kaduna Metropolis, Nigeria. Int Res J Pure Appl Chem 2015; 5(3):20-9.

10. Njoroge GK, Njagi EN, Orinda GO, SekaddeKigondu CB, Kayima JK. Environmental and occupational exposure to lead. East Afr Med J 2008; 85(6):284-91. 
11. Flora G, Gupta D, Tiwari A. Toxicity of lead: A review with recent updates. Interdiscip Toxicol 2012; 5(2):47-58.

12. Omotosho IO. Oxidative Stress Indices as Markers of Lead and Cadmium Exposure Toxicities in Auto Technicians in Ibadan, Nigeria. Oxid Med Cell Longev 2019; 2019:3030614.

13. D'souza AP. Unorganized Sector: Role of an Enterpreneur and Challenges in Self Employment. International Journal of Scientic and Research Publications 2013; 3(6):1-5.

14. Hsieh $\mathrm{NH}$, Chung $\mathrm{SH}$, Chen SC, Chen WY, Cheng $\mathrm{YH}$, Lin YJ, et al. Anaemia risk in relation to lead exposure in lead - related manufacturing. BMC Public Health 2017; 17(1):389.

15. Kshirsagar M, Patil J, Patil A, Ghanwat G, Sontakke A, Ayachit RK. Effects of Lead on Haeme Biosynthesis and Heamatological Parameters in Battery Manufacturing Workers of Western Maharashtra India. Journal of Pharmaceutical, Chemical and Biological Sciences 2016; 3(4):477-87.

16. Ray RR. Haemotoxic Effects of Lead: A Review. Proc Zool Soc 2016; 69(2):161-72.

17. Barman T, Kalahasthi R, Rajmohan HR. Effects of lead exposure on the status of platelets indices in workers involved in a lead - acid battery manufacturing plant. J Expo Sci Environ Epidemiol 2014; 24(6):629-33.

18. Prüss-üstün $A$, Fewtrell $L$, Landrigan $P J$, Ayuso-mateos JL. Lead Exposure. In: Ezzati M, Lopez AD, Rodgers A, Murray CJL, editors. Comp Quantification of Health Risks: Global and Regional Burden of Disease Attributable to Selected Major Risk Factors. 1st ed. Geneva, Switzerland: World Health Organization; 2004. P.1495-542.

19. Ghasemi A, Nakhaei AA, Ghamseri AA, Salehi $M$, Kalani-Moghaddam F. Anaemia, Iron Deficiency Anaemia, and Lead Poisoning in Children with Opiod Toxicity: A Study in North East of Iran. Iran J Ped Hematol Oncol 2017; 7(2):90-7.

20. Hegazy AA, Zaher MM, Abd El-Hafez MA, Morsy AA, Saleh RA. Relation between anaemia and blood levels of lead, copper, zinc and iron among children. BMC Res Notes 2010;
3:133.

21. Aniebue PN, Aguwa EN, Obi El. Universal precautions: Awareness and practice of patent medicines vendors in Enugu metropolis, south east Nigeria. Niger Med J 2010; 51(1):30-4.

22. Ofili AN, Usiholo EA, Oronsaye MO. Psychological morbidity, job satisfaction and intentions to quit among teachers in private secondary schools in Edo-State, Nigeria. Ann Afr Med 2009; 8(1):32-7.

23. Prüss-Üstün A, Mathers $C$, Corval án $C$, Woodward A. Introduction and methods: Assessing the environmental burden of disease at national and local levels. Geneva, Switzerland: World Health Organization; 2003. (World Health Organization, Environmental Burden of Disease Series, No. 1)

24. Minnesota Department of Health. Occupational Health and Safety Data, Occupational Lead Exposure in Adults. Saint Paul, Minnesota, United States: Minnesota Department of Health; 2018 Dec.

25. Addai-Mensah O, Gyamfi D, Duneeh RV, Danquah KO, Annani-Akollor ME, Boateng L, et al. Determination of Haematological Reference Ranges a Healthy Adult in Three Regions in Ghana. Biomed Res Int 2019; 2019:7467512.

26. Al Khatib AJ, Taani HM, Al Asseiri M, Qasem AM, Kassab M, Laiche F. Haematological Changes in Prisoners with Higher Blood Levels Compared with General Population. Eur Sci J 2013; 9(36):342-34.

27. Al-Ameen AM, Bashir FY. Effects of direct exposure to lead on some haematological parameters among battery repairs workers in Mosul. Annals of College of Medicine 2008; 34(1):58-63.

28. Taha G.E.M, Afify M.M, Elmalah W.M, Gaber M.R. Impacts of Blood Lead Level on Trace Elements Status and Haematological Parameters in Anemic Children from Beni Suef, Egypt. J Clin Toxicol 2018; 8(2):1000383.

29. Fazli D, Malekirad AA, Mirzaee M, Dastjerdi HA, Mostafalou S, Karkhane A, et al. Study on the Link between Lead Exposure and Haematological, Psychological and Memorial Parameters in Automobile Repair Workers. Health 2014; 6(8):712-9. 